\title{
Establishment of a viable cell detection system for microorganisms in wine based on ethidium monoazide and quantitative PCR
}

\author{
Hui Shi ${ }^{a}$, Wentao Xu ${ }^{\mathrm{a}, *}$, Quoclinh Trinh ${ }^{\mathrm{a}}$, Yunbo Luo ${ }^{\mathrm{a}, \mathrm{b}}$, Zhihong Liang ${ }^{\mathrm{b}}$, Yingcong Li $^{\mathrm{c}}$, Kunlun Huang ${ }^{\mathrm{a}, \mathrm{b}, *}$ \\ ${ }^{a}$ Laboratory of Food Safety, College of Food Science and Nutritional Engineering, China Agricultural University, Beijing 100083, China \\ ${ }^{\mathrm{b}}$ Supervision E' Testing Center of Agricultural Products Quality, Ministry of Agriculture, Beijing 100083, China \\ ${ }^{\mathrm{c}}$ Institute of Psychology, Chinese Academy of Sciences, Beijing 100101, China
}

\section{A R T I C L E I N F O}

\section{Article history:}

Received 21 December 2011

Received in revised form 25 February 2012

Accepted 28 February 2012

\section{Keywords:}

Cell viability

Wine

Ethidium monoazide

Quantitative PCR

\begin{abstract}
A B S T R A C T
Fermentability and contamination level of wine can be assessed through the detection of viable fermentation-related and spoilage-related microorganisms. Ethidium monoazide in combination with quantitative PCR (EMA-qPCR) has been considered as a promising method to enumerate viable cells. Milling for $80 \mathrm{~s}$ by $\emptyset 500-\mu \mathrm{m}$ glass beads is demonstrated to be optimal for DNA extraction from yeasts, lactic acid bacteria ( $\mathrm{LAB}$ ) and acetic acid bacteria (AAB) in wine to be used as a template for PCR. EMAqPCR results from experiments using DNA extracted by this method correlate well with the results of a plating assay $\left(R^{2}>0.99\right)$, and a PCR efficiency between $96 \%$ and $105 \%$ was obtained. Moreover, for all of these microorganisms, EMA treatment of pure cultures at a low concentration $(10 \mu \mathrm{g} / \mathrm{mL})$ for $20 \mathrm{~min}$ photoactivation resulted in effective differentiation between viable and non-viable cells and had no effect on viable cells. Due to sublethal injury to some cells, underestimation of cell counts was found in most of the wine samples tested using the EMA-qPCR method, and a 40-min incubation in recovery medium could completely offset this error. Our results suggest an optimal glass-bead DNA extraction method and EMA treatment suitable for all of the main microorganisms in wine. The EMA-qPCR method was successfully applied to quantify yeasts, Saccharomyces cerevisiae (S. cerevisiae), LAB, non-Oenococcus oeni $\mathrm{LAB}$ (non-O. oeni $\mathrm{LAB}$ ) and $\mathrm{AAB}$ in wine samples.
\end{abstract}

(c) 2012 Elsevier Ltd. All rights reserved.

\section{Introduction}

The transformation of grape must into wine is a complex microbiological process that involves different yeast and bacteria species present in grapes, on vineyard equipment and in cellars (Amerine et al., 1980). The whole fermentation process includes alcoholic fermentation and malolactic fermentation. Yeasts have been reported as the main microorganisms to accomplish alcoholic fermentation. Among them, Saccharomyces cerevisiae is the predominant species, and it plays a beneficial role because of its good fermentation abilities (Martorell, Querol, \& FernándezEspinar, 2005). In the secondary malolactic fermentation (MLF), Lmalate is converted to L-lactate by LAB existing in wine, leading to better sensory quality and greater microbiological stability of the wine (López et al., 2011; Ruiz, Izquierdo, Seseña, \& Palop, 2010).

\footnotetext{
* Corresponding authors. Laboratory of Food Safety, College of Food Science and Nutritional Engineering, China Agricultural University, Beijing 100083, China. Tel.: +86106273 6479; fax: +861062737786.

E-mail addresses: cauxwt@yahoo.cn, xuwentaoboy@sina.com (W. Xu) huangkl009@sina.com (K. Huang).
}

Oenococcus oeni (O. oeni) usually becomes the dominant LAB species mainly due to its high tolerance to ethanol $(>10 \%)$ and acidic environments $(\mathrm{pH}<3.5$ ). Moreover, $O$. oeni is considered to be the best choice of inoculum because it is less prone to produce undesirable flavors than wine-related non-O. oeni LAB (Versari, Parpinello, \& Cattaneo, 1999). However, LAB can become contaminants after fermentation if they are not eliminated or they contaminate wine during storage, and non-O. oeni LAB can especially indicate the spoilage potential of the LAB population in wines (Amerine \& Roessler, 1983; Neeley, Phister, \& Mills, 2005). Yeasts are also able to spoil wines after fermentation by altering the chemical composition of wine, and detracting from its sensory properties of appearance, aroma, and taste (Andorrà, EsteveZarzoso, Guillamón, \& Mas, 2010; Martorell et al., 2005) In addition, $A A B$ are another concern because they can cause serious spoilage in wine (Jara, Mateo, Guillamón, Torija, \& Mas, 2008). Therefore, it is necessary to detect total yeasts, $S$. cerevisiae, total $\mathrm{LAB}$, non- $O$. oeni $\mathrm{LAB}$ and total $\mathrm{AAB}$ in wine. Through the investigation of fermentation-related and spoilage-related microorganisms, the fermentability and spoilage potential of wine can be rapidly assessed. 
The traditional cultivation-based methods for enumerating microorganisms are time-consuming and labor-intensive. Molecular detection techniques have demonstrated advantages such as higher efficiency and sensitivity compared to traditional methods. Quantitative PCR (qPCR) is a robust molecular method that has been developed to detect total yeasts, $S$. cerevisiae, total $L A B$, nonO. oeni LAB and total AAB in wine (Hierro, Esteve-Zarzoso, González, Mas, \& Guillamón, 2006; Jara et al., 2008; Martorell et al., 2005; Neeley et al., 2005). An ethidium monoazide bromide (EMA) qPCR (EMA-qPCR) method has been described as a promising method to discriminate viable and non-viable cells (Nocker, Cheung, \& Camper, 2006; Nogva, Drømtorp, Nissen, \& Rudi, 2003; Shi et al., 2011). EMA, a DNA-intercalating dye that can only penetrate cells with compromised membranes, covalently binds to DNA through photoactivation, consequently inhibiting subsequent qPCR. This EMA-qPCR method has been used for viable yeast detection in wine (Andorrà et al., 2010; Rawsthorne \& Phister, 2009a,b). To the best of our knowledge, no studies have been performed using this method on other wine microorganisms. Further studies are necessary for the establishment of a viable cell detection system in wine. First, to precisely monitor and analyze the fermentation process and wine contamination, simultaneous detection of major viable microorganisms in wine should be performed. Therefore, the universal DNA extraction protocol, EMA treatment and QPCR procedure should be optimized for these microorganisms. Moreover, wine is a complex matrix, so attention should be paid to whether this matrix can interfere with DNA extraction and EMA-DNA binding for different microorganisms. Finally, although EMA demonstrates more effective penetration into damaged cells and greater PCR inhibition ability than the alternative dye propidium monoazide (PMA) (Lee \& Levin, 2008), high concentrations of EMA may penetrate into viable cells and cause false negative results (Nocker et al., 2006; Nogva et al., 2003; Rudi, Moen, Drømtorp, \& Holck, 2005). Therefore, EMA concentration and light exposure time must be optimized to achieve accurate results. In addition, glass-bead DNA extraction protocol has been described as an efficient DNA isolation method and been applied in yeasts and bacteria respectively (Hierro et al., 2006; Lemarchand et al., 2005; Williamson, Kan, Polson, \& Williamson, 2011). In our study, this method was optimized for wine microorganisms (yeasts, $\mathrm{LAB}$, and $\mathrm{AAB}$ ) DNA extraction in order to isolate DNA from these microorganisms in wine simultaneously.

The objectives of this study were the following: (i) to determine a high-efficiency glass-bead DNA extraction protocol for wine microorganisms, including yeasts, $\mathrm{LAB}$ and $\mathrm{AAB}$, (ii) to determine the optimum EMA treatment for simultaneous detection of fungi and bacteria in wine, and (iii) to validate the utility of the EMAqPCR method for the detection of various viable microorganisms simultaneously in wine.

\section{Materials and methods}

\subsection{Microbial strains and culture conditions}

Seven strains were used in this study: S. cerevisiae W303-1A, Zygosaccharomyces bailii ATCC 56075, Candida utilis AS2.120, Lactobacillus brevis AS1.12, Lactobacillus plantarum AS 1.2986, Acetobacter aceti ATCC 15973 and Acetobacter pasteurianus ATCC 33445 . Yeasts were cultured in YPD ( $2 \%$ glucose, $2 \%$ peptone and $1 \%$ yeast extract, w/v) at $30{ }^{\circ} \mathrm{C}$ for $24 \mathrm{~h}$. LAB were cultured in MRS (Difco, Maryland, USA) at $37^{\circ} \mathrm{C}$ for $24 \mathrm{~h}$. AAB were cultured in GYC ( $5 \%$ glucose, $1 \%$ yeast extract and $2 \% \mathrm{CaCO}_{3}, \mathrm{w} / \mathrm{v}$ ) at $30{ }^{\circ} \mathrm{C}$ for 2 days. The CFU counts were determined by plating serial 10 -fold dilutions of the cultures on corresponding solid medium, and colony counts (in CFU) were determined in triplicate. In addition, the selective media used in this study to enumerate microorganisms in contaminated wines included MRS agar with $3 \mathrm{~g} / \mathrm{L}$ phenylethanol and $7 \mathrm{mg} / \mathrm{L}$ cycloheximide (selective for LAB; Saha, Sondag, \& Middlekauff, 1974); yeast extract glucose chloramphenicol (selective for yeasts; Rea et al., 1996); Acetobacter peroxydans medium (selective for AAB; Witthuhn, Schoeman, \& Britz, 2004). PCR amplifications with specific primers were performed for identification of S. cerevisiae or non-O. oeni LAB colonies on the selective media for yeasts or LAB.

\subsection{Glass-bead DNA extraction method for yeasts, $L A B$ and $A A B$}

Five hundred microliters of each cell culture which was about $10^{8} \mathrm{CFU} / \mathrm{mL}$ (S. cerevisiae, Zygosaccharomyces bailii (Z. bailii), Candida utilis (C. utilis), Lactobacillus brevis (L. brevis), Lactobacillus plantarum (L. plantarum), Acetobacter aceti (A. aceti), and Acetobacter pasteurianus (A. pasteurianus)) was resuspended in wine of equal volume for $30 \mathrm{~min}$ after centrifugation. The cultures were then centrifuged at $12,000 \mathrm{rpm}$ for $5 \mathrm{~min}$, and the supernatant was removed. The pellet was suspended with $0.2 \mathrm{~mL}$ lysis solution (Tris- $\mathrm{HCl} 10 \mathrm{mM} \mathrm{pH} 8$, EDTA $1 \mathrm{mM}$, NaCl $100 \mathrm{mM}$, SDS 1\% (w/v), Triton X-100 2\% (w/v)). Next, $0.2 \mathrm{~mL}$ phenol: chloroform: isoamyl alcohol (IAA) 25:24:1, $0.3 \mathrm{~g}$ glass beads of $\varnothing 106-\mu \mathrm{m}$ or $500-\mu \mathrm{m}$ (Sigma, USA) and $1 \%(\mathrm{w} / \mathrm{v})$ polyvinyl polypyrrolidone (PVPP), to remove inhibitors, were added simultaneously. Cells were mechanically disrupted using $2,4,6$ or 8 agitation cycles of $20 \mathrm{~s}$ each with a Biospec Beadbeater (BioSpec, Bartlesville, USA). Subsequently, phenol-chloroform extractions were performed, and the supernatant was subjected to ethanol precipitation. Finally, the extracted genomic DNA was dissolved in

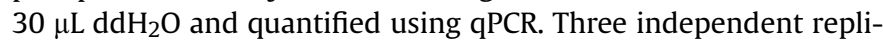
cates were performed as independent treatments, and DNA extractions were performed on separate days.

\section{3. $q P C R$}

QPCR and data analysis were performed on an Applied Biosystems 7000 Real-Time PCR system (Applied Biosystems, Foster city, CA). The quantification was performed with the primers YEASTF/YEASTR for total yeasts (amplification of a 124-bp fragment) (Hierro et al., 2006), SC1d/SC1r for $S$. cerevisiae (301 bp) (Martorell et al., 2005), WLAB1/WLAB2 for total LAB (408 bp) (Lopez et al., 2003), LAC1/LAC2 for non-O. oeni LAB (344 bp) (Lopez et al., 2003), and AQ1F/AQ2R (55 bp) for total AAB (González, Hierro, Poblet, Mas, \& Guillamón, 2006). All qPCR reactions were performed in a total volume of $30 \mu \mathrm{L}$ containing $12 \mu \mathrm{L}$ of Sybrgreen Mix (Takara Bio, Inc., Kyoto, Japan), $1.0 \mu \mathrm{L}$ of $0.5 \mu \mathrm{M}$ forward primer and $1.0 \mu \mathrm{L}$ of $0.5 \mu \mathrm{M}$ reverse primer, $2 \mu \mathrm{L}$ of extracted genomic DNA and $14 \mu \mathrm{L}$ of deionized water. Cycling parameters for qPCR included an initial denaturation at $95{ }^{\circ} \mathrm{C}$ for 5 min followed by 35 cycles of $95^{\circ} \mathrm{C}$ for $30 \mathrm{~s}, 60^{\circ} \mathrm{C}$ for $30 \mathrm{~s}$, and primer extension at $72{ }^{\circ} \mathrm{C}$ for $60 \mathrm{~s}$. The fluorescent products were detected after the extension step of each cycle. In analysis of qPCR data, threshold was corrected to the same value in all experiments.

\subsection{Creation of standard curves for three microorganisms in wine}

To determine the population of each species, standard curves were created to make correlations between qPCR and plate counts. The standard curves of total $L A B$ and non-O. oeni $L A B$ population were generated with $L$. brevis; the standard curves for total yeasts and $S$. cerevisiae were generated with $S$. cerevisiae; and the standard curves for total AAB were generated with A. aceti. Non-viable cells were obtained by heating cell suspensions at $85{ }^{\circ} \mathrm{C}$ for $20 \mathrm{~min}$, resulting in a decrease in culturable cell counts to zero. For these three microorganisms, 10 -fold serial dilutions of viable cells were 
made in corresponding heat-killed cell suspensions (total volume of $1 \mathrm{~mL}$ in wine) and subjected to DNA extraction and EMA-qPCR, giving standard curves of $10^{7}, 10^{6}, 10^{5}, 10^{4}, 10^{3}, 10^{2} \mathrm{CFU} / \mathrm{mL}$ viable cells. The efficiency $(E)$ of the qPCR assay was calculated using the formula

$E=10^{-1 / \text { slope }}-1$.

\subsection{Optimization of the EMA treatment}

EMA (phenanthridium, 3-amino-8-azide-5-ethyl-6-phenyl bromide; Biotium, Hayward, CA, USA) was dissolved in $20 \%$ DMSO to a stock concentration of $5 \mathrm{mg} / \mathrm{mL}$ and stored in the dark at $-20{ }^{\circ} \mathrm{C}$. To optimize EMA concentration, $500 \mu \mathrm{L}$ of each culture was placed in $1.5-\mathrm{mL}$ microcentrifuge tubes and killed by heating them at $85^{\circ} \mathrm{C}$ for $20 \mathrm{~min}$. Different amounts of EMA were added to the $500-\mu \mathrm{L}$ cell aliquots to various final concentrations: $0,5,10,25$, 50 or $100 \mu \mathrm{g} / \mathrm{mL}$. The samples were incubated in the dark for $10 \mathrm{~min}$. Tubes (with lids removed) were then placed in crushed ice and exposed to a 500-W halogen light for $5 \mathrm{~min}$ at a distance of $10 \mathrm{~cm}$. To optimize EMA photoactivation time, the cells were prepared as described above and were then either heat-killed as above or kept alive. EMA $(10 \mu \mathrm{g} / \mathrm{mL})$ was added to all of the samples before incubating them in the dark. The dead and viable cells were both exposed to the light source for $0,5,10,15$ or $20 \mathrm{~min}$.

\subsection{Analysis of microflora in contaminated wines}

To further examine the method, DNA was extracted from 5 contaminated wines (Cabernet sauvignon, Merlot, Petit Verdot, Chardonnay and Sauvignon Blanc), and total yeasts, S. cerevisiae, total $\mathrm{LAB}$, non-O. oeni $\mathrm{LAB}$ and total $\mathrm{AAB}$ population were determined by plating, qPCR, and EMA-qPCR. Cells can be sublethally injured by ethanol and acid pressure in wine, allowing EMA penetration. To prevent the underestimation of cells by EMA-qPCR, recovery medium ( $2 \%$ glucose, $1 \%$ peptone and $1 \%$ yeast extract, $w /$ v) was prepared, and populations were incubated for $40 \mathrm{~min}$ in recovery medium and subsequently enumerated by EMA-qPCR. To examine whether incubation in recovery medium can increase cell counts, these population numbers were also determined by plating on selective media after incubation in recovery medium. To increase the detection limit, the wine was concentrated 10 -fold by centrifugation.

\subsection{Statistical analysis}

All experiments were carried out in triplicate. The significance of the results was analyzed using ANOVA (Duncan or Dunnett) or Student's $t$-test. Differences were considered significant at $P<0.05$.

\section{Results}

\subsection{Optimization of a glass-bead protocol for DNA isolation from yeasts, $L A B$ and $A A B$ in wine}

The effects of bead size and milling time on the quality of DNA extracted for PCR from S. cerevisiae, Z. bailii, C. utilis, L. brevis, L. plantarum, A. aceti and $A$. pasteurianus in wine were shown in Table 1 . As the milling time of $\emptyset 106-\mu \mathrm{m}$ glass beads increased from $40 \mathrm{~s}$ to $160 \mathrm{~s}$ (20 s per agitation cycle), the Ct values of yeasts (S. cerevisiae, Z. bailii and C. utilis) DNA decreased accordingly and reached their minimum of $9.08 \pm 0.36,9.01 \pm 0.52$ and $9.05 \pm 0.29$ respectively at $160 \mathrm{~s}$ milling time. On the other hand, the Ct values of LAB (L. brevis, L. plantarum) decreased accordingly and reached their plateaus of $8.82 \pm 0.48$ and $8.99 \pm 0.24$ at $80 \mathrm{~s}$ milling time, and the $\mathrm{Ct}$ values of $\mathrm{AAB}$ ( $A$. aceti and $A$. pasteurianus) also decreased accordingly and reached their plateaus of $7.34 \pm 0.38$ and $7.60 \pm 0.36$ at $80 \mathrm{~s}$ milling time. As the milling time of $\varnothing 500-\mu \mathrm{m}$ glass beads increased from $40 \mathrm{~s}$ to $160 \mathrm{~s}$ ( $20 \mathrm{~s}$ per agitation cycle), the Ct values of S. cerevisiae, Z. bailii, C. utilis, L. brevis, L. plantarum, A. aceti and $A$. pasteurianus decreased accordingly and reached their plateaus of $8.84 \pm 0.30,8.69 \pm 0.35,8.80 \pm 0.38,8.84 \pm 0.28$, $8.99 \pm 0.36,7.32 \pm 0.44$ and $7.62 \pm 0.37$, respectively, at $80 \mathrm{~s}$ milling time (Table 1 ). Hence, milling for $80 \mathrm{~s}$ by $\varnothing 500-\mu \mathrm{m}$ glass beads could be considered to be the optimal condition to extract sufficient DNA from yeasts, LAB and AAB in wine for PCR. Moreover, qPCR results of DNA extracted in this manner for five assays of total $L A B$, non-O. oeni $\mathrm{LAB}$, total yeasts, $S$. cerevisiae and $\mathrm{AAB}$ correlated well with the plating results $\left(R^{2}>0.99\right)$ (Fig. 1). Additionally, PCR efficiency ranging between $96 \%$ and $105 \%$ was obtained (Fig. 1).

\subsection{Optimization of EMA treatments}

EMA combines with DNA of dead cells and inhibits PCR amplification. Hence, the Ct value of DNA from dead cells with EMA binding is higher than that of viable cells without EMA binding. The effects of EMA concentration and photoactivation time on PCR inhibition were studied to determine the optimal EMA treatments to achieve the highest $\Delta \mathrm{Ct}$ (with EMA - without EMA). The three main microorganisms in wine were all investigated to determine the conditions under which the EMA-qPCR method could be used in wine with the highest efficacy. As shown in Fig. 2 A1, B1 and C1, the maximum $\Delta \mathrm{Ct}$ was achieved at an EMA concentration of $10 \mu \mathrm{g} /$ $\mathrm{mL}$ for yeasts, $\mathrm{LAB}$ and $\mathrm{AAB}$ cultures of approximately $10^{7} \mathrm{CFU} / \mathrm{mL}$. Moreover, there were no significant differences $(P>0.05)$ in the $\Delta \mathrm{Ct}$ values for these microorganisms treated with different EMA concentrations of $10,25,50$ and $100 \mu \mathrm{g} / \mathrm{mL}$. The $\Delta \mathrm{Ct}$ increased significantly $(P<0.05)$ as the photoactivation time increased from $0 \mathrm{~min}$ to $20 \mathrm{~min}$ for the non-viable yeasts, $\mathrm{LAB}$ and $\mathrm{AAB}$ at $10 \mu \mathrm{g} / \mathrm{mL}$

Table 1

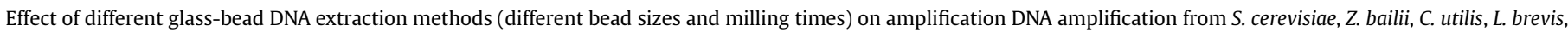
L. plantarum, A. aceti and A. pasteurianus.

\begin{tabular}{|c|c|c|c|c|c|c|c|c|}
\hline \multirow{3}{*}{$\frac{\text { Size of beads }}{\text { Milling time }}$} & \multicolumn{8}{|c|}{$\mathrm{Ct}$ values from qPCR } \\
\hline & \multicolumn{4}{|l|}{$106-\mu \mathrm{m}$} & \multicolumn{4}{|l|}{$500-\mu \mathrm{m}$} \\
\hline & $40 \mathrm{~s}$ & $80 \mathrm{~s}$ & $120 \mathrm{~s}$ & $160 \mathrm{~s}$ & $40 \mathrm{~s}$ & $80 \mathrm{~s}$ & $120 \mathrm{~s}$ & $160 \mathrm{~s}$ \\
\hline S. cerevisiae & $10.48 \pm 0.26$ & $9.68 \pm 0.42$ & $9.36 \pm 0.31$ & $9.08 \pm 0.36$ & $9.72 \pm 0.25$ & $8.84 \pm 0.30$ & $8.98 \pm 0.32$ & $8.97 \pm 0.19$ \\
\hline Z. bailii & $10.34 \pm 0.34$ & $9.62 \pm 0.21$ & $9.20 \pm 0.44$ & $9.01 \pm 0.52$ & $9.66 \pm 0.31$ & $8.69 \pm 0.35$ & $8.76 \pm 0.29$ & $8.78 \pm 0.27$ \\
\hline C. utilis & $10.41 \pm 0.35$ & $9.58 \pm 0.47$ & $9.39 \pm 0.28$ & $9.05 \pm 0.29$ & $9.68 \pm 0.34$ & $8.80 \pm 0.38$ & $8.92 \pm 0.27$ & $8.93 \pm 0.18$ \\
\hline L. brevis & $9.11 \pm 0.41$ & $8.82 \pm 0.48$ & $8.84 \pm 0.33$ & $8.82 \pm 0.27$ & $8.90 \pm 0.35$ & $8.84 \pm 0.28$ & $8.83 \pm 0.19$ & $8.84 \pm 0.18$ \\
\hline L. plantarum & $9.33 \pm 0.65$ & $8.99 \pm 0.24$ & $9.02 \pm 0.41$ & $8.99 \pm 0.33$ & $9.19 \pm 0.27$ & $8.99 \pm 0.36$ & $8.95 \pm 0.38$ & $8.98 \pm 0.31$ \\
\hline A. aceti & $7.80 \pm 0.27$ & $7.34 \pm 0.38$ & $7.37 \pm 0.21$ & $7.35 \pm 0.28$ & $7.76 \pm 0.26$ & $7.32 \pm 0.44$ & $7.34 \pm 0.27$ & $7.33 \pm 0.34$ \\
\hline A. pasteurianus & $7.99 \pm 0.32$ & $7.60 \pm 0.36$ & $7.63 \pm 0.28$ & $7.61 \pm 0.27$ & $7.87 \pm 0.32$ & $7.62 \pm 0.37$ & $7.63 \pm 0.31$ & $7.61 \pm 0.46$ \\
\hline
\end{tabular}

Standard deviations are from three independent replicates. 

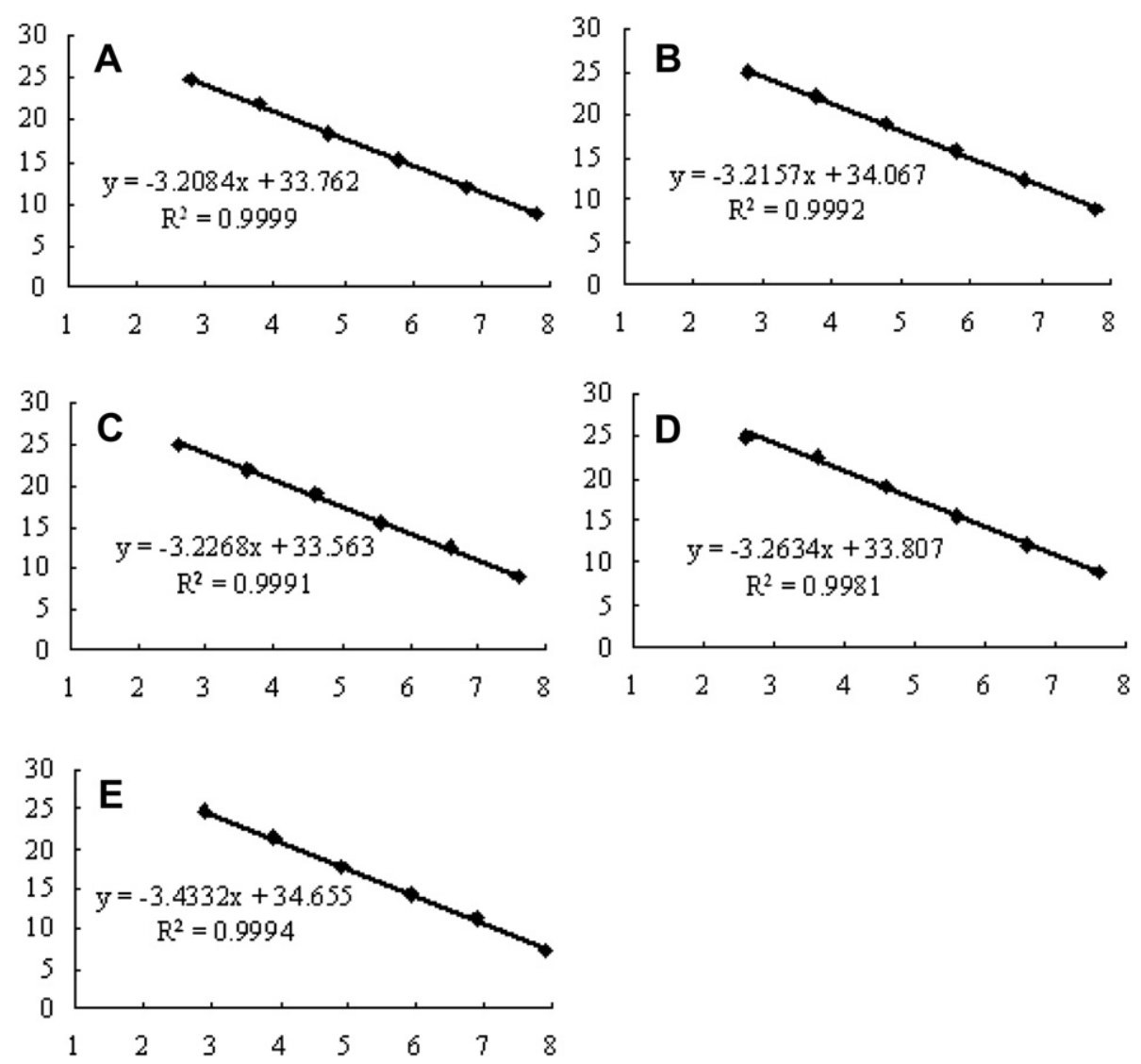

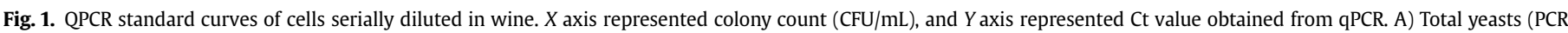

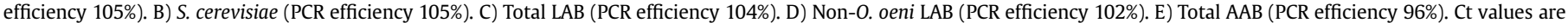
averages of results from three replicates.

EMA, as shown in Fig. 2 A2, B2 and C2, but this effect was not observed among viable cells. Simultaneously, the $\Delta \mathrm{Ct}$ was determined for all three microorganisms at $10^{2}-10^{6} \mathrm{CFU} / \mathrm{mL}$, and the $\Delta \mathrm{Ct}$ values were enough to discriminate between viable and non-viable cells with a minimum $\Delta \mathrm{Ct}$ value of $3.31,3.70$ and 3.41 at $10^{2} \mathrm{CFU} / \mathrm{mL}$ for yeasts, $\mathrm{LAB}$ and $\mathrm{AAB}$, respectively. Therefore, we suggest that for using the EMA-qPCR method in wine the optimal EMA concentration is $10 \mu \mathrm{g} / \mathrm{mL}$, and the optimal photoactivation time is $20 \mathrm{~min}$.

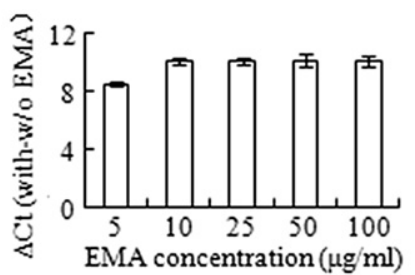

A1

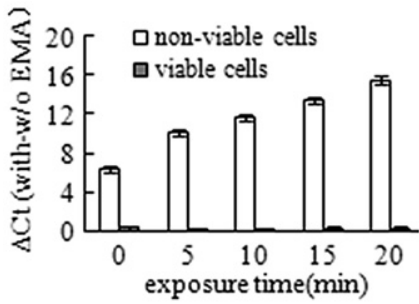

A2

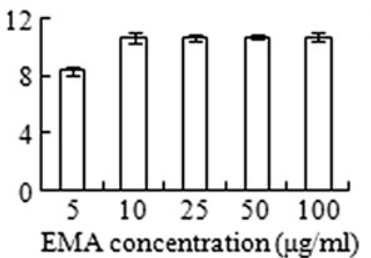

B1

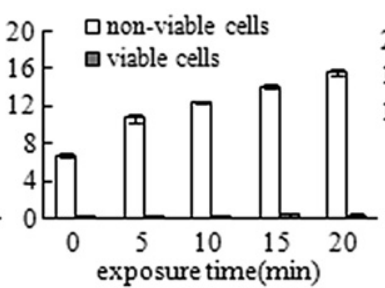

B2

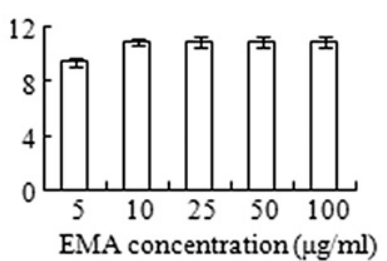

$\mathrm{C} 1$

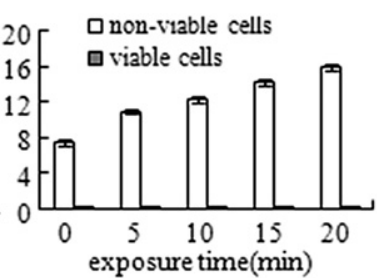

$\mathrm{C} 2$

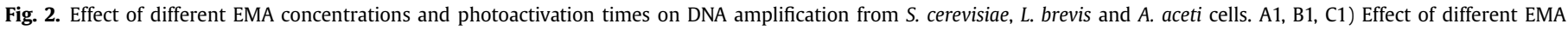

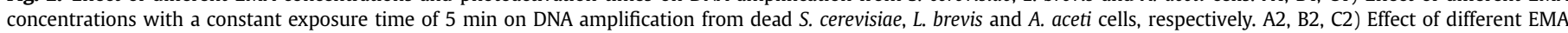

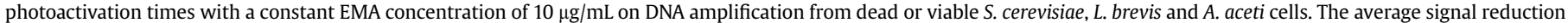

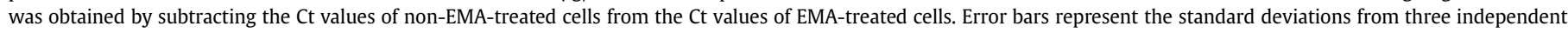
replicates. 


\subsection{Detection of viable yeasts, $L A B$ and $A A B$ in contaminated wine}

Total yeasts, $S$. cerevisiae, total $\mathrm{LAB}$, non-O. oeni $\mathrm{LAB}$ and total $A A B$ were detected in five contaminated wines by a plating assay and the EMA-qPCR method (Table 2). EMA-qPCR always gave lower estimations of the five microbial populations than did the plating result. Only in the merlot wine sample was the plating result significantly lower than the counts obtained by EMA-qPCR enumeration. However, the EMA-qPCR counts significantly increased after a 40-min incubation in recovery medium and almost matched the plate counts for yeasts, LAB and AAB. On the other hand, plate count results did not change after a 40-min incubation in recovery medium, which indicated that a $40-\mathrm{min}$ incubation in recovery medium did not increase the cell number. This shows that the yeasts, $L A B$ and $A A B$ in wine could completely recover from sublethal injury, and EMA could not penetrate them after a 40 -min incubation in recovery medium.

\section{Discussion}

In this study, we described a standardized glass-bead DNA extraction method for the main microorganisms in wine, including yeasts, $L A B$ and $A A B$. First, our results showed that for yeasts, milling by glass beads of $\emptyset 500-\mu$ m caused more complete cell lysis that yielded DNA of higher concentration for the subsequent PCR than milling by beads of $\varnothing 106-\mu \mathrm{m}$; however, the lysis effects of $106-\mu \mathrm{m}$ and $500-\mu \mathrm{m}$ glass beads on bacteria such as LAB and AAB were almost identical. In addition, the amount of DNA detected by qPCR increased as milling time increased until reached a platform by both the $\varnothing 500-\mu \mathrm{m}$ and $\emptyset 106-\mu \mathrm{m}$ glass beads. Moreover, many substances that are present in wine, such as polysaccharides and a range of polyphenolics, can cause poor DNA isolation and PCR efficiency. It has been reported that insoluble PVPP addition during DNA extraction succeeded in removing PCR inhibitors from wine and resulted in efficient isolation of Brettanomyces DNA (Tessonnière, Vidal, Barnavon, Alexandre, \& Remize, 2009). PVPP addition is also successfully used in DNA extraction of yeasts, LAB and $A A B$ in wine in our study. In this study, the optimal glass-bead protocol for DNA extraction (milling for $80 \mathrm{~s}$ by $500-\mu \mathrm{m}$ glass beads) is described for total DNA extraction of wine microorganisms, and a universal PCR procedure for five species (yeasts, $S$. cerevisiae, $\mathrm{LAB}$, non- $O$. oeni $\mathrm{LAB}$ and $\mathrm{AAB}$ ) is provided.

In fermented foods like wine, it is especially crucial to quantify viable cells because fermentation and contamination both directly result from microbial metabolism and activity. Previous qPCR quantification of wine microorganisms often gave larger population estimates than the plating results because qPCR could amplify DNA from both viable and non-viable cells in wine (Neeley et al., 2005). EMA treatment prior to qPCR is a promising viable cell detection method, and it can penetrate damaged cells more effectively than its comparable nucleic acid dye PMA, leading to greater PCR inhibition (Lee \& Levin, 2008). However, it has been questioned mainly because the addition of high concentrations of EMA resulted in its penetration into viable cells, causing underestimates of viable cell numbers (Flekna et al., 2007). In our study, EMA treatment was optimized for the first time for both fungi (yeasts) and bacteria (LAB and $A A B$ ) to achieve uniform and efficient conditions for using this method in wine. The results indicate that $10 \mu \mathrm{g} / \mathrm{mL}$ is the minimum EMA concentration necessary to inhibit PCR amplification of DNA from dead yeasts, $L A B$ and $A A B$ cells. In addition, greater inhibition effects occur with increased photoactivation time with the most obvious effect (as indicated by the $\Delta \mathrm{Ct}$ ) occurring with $20 \mathrm{~min}$ of light exposure for all of the three species. However, EMA has little effect on viable cells with this low concentration and long exposure time (Fig. 2). This result suggests the optimal EMA treatment for viable cell detection in wine and indicates the wider application of EMA dye with no effect on viable cells.

Contaminated wine samples were analyzed by EMA-qPCR and plate counts with and without recovery medium. For microorganisms, wine represents a stressed environment with a high ethanol concentration and low $\mathrm{pH}$. Various environmental stresses (including ethanol and acids) can induce genes regulating the stress response and cause sublethal injury of the cell (Abee \& Wouters, 1999; Dickson \& Siragusa, 1994). Sublethal injury is

Table 2

Enumeration by plating and EMA-qPCR of total yeasts, S. cerevisiae, total LAB, non-O. oeni and total AAB in contaminated wines.

\begin{tabular}{|c|c|c|c|c|c|c|}
\hline & & \multicolumn{5}{|l|}{ Wine varietal } \\
\hline & & Cabernet sauvignon & Merlot & Petit Verdot & Chardonnay & Sauvignon Blanc \\
\hline \multirow[t]{5}{*}{ Total yeasts } & QPCR & $3.57 \pm 0.60 \times 10^{4}$ & $2.21 \pm 0.47 \times 10^{4}$ & $4.27 \pm 0.28 \times 10^{4}$ & $9.72 \pm 0.56 \times 10^{4}$ & $9.21 \pm 0.39 \times 10^{3}$ \\
\hline & EMA-qPCR & $1.32 \pm 0.26 \times 10^{3}$ & $9.01 \pm 0.56 \times 10^{2}$ & $9.11 \pm 0.44 \times 10^{2}$ & $9.49 \pm 0.37 \times 10^{2}$ & $9.67 \pm 0.38 \times 10^{2}$ \\
\hline & EMA-qPCR $^{\mathrm{a}}$ & $9.21 \pm 0.38 \times 10^{3}$ & $9.20 \pm 0.43 \times 10^{2}$ & $7.67 \pm 0.46 \times 10^{3}$ & $1.03 \pm 0.33 \times 10^{4}$ & $5.23 \pm 0.45 \times 10^{3}$ \\
\hline & Plating & $9.52 \pm 0.67 \times 10^{3}$ & $8.19 \pm 0.82 \times 10^{1}$ & $7.90 \pm 0.91 \times 10^{3}$ & $1.25 \pm 0.78 \times 10^{4}$ & $5.41 \pm 1.08 \times 10^{3}$ \\
\hline & Plating $^{\mathrm{a}}$ & $9.59 \pm 0.66 \times 10^{3}$ & $8.32 \pm 0.90 \times 10^{1}$ & $7.98 \pm 0.58 \times 10^{3}$ & $1.32 \pm 0.83 \times 10^{4}$ & $5.49 \pm 0.68 \times 10^{3}$ \\
\hline \multirow[t]{5}{*}{ S. cerevisiae } & QPCR & $9.98 \pm 0.34 \times 10^{3}$ & $2.33 \pm 0.53 \times 10^{3}$ & $1.26 \pm 0.79 \times 10^{4}$ & $3.67 \pm 0.54 \times 10^{4}$ & $2.34 \pm 0.67 \times 10^{3}$ \\
\hline & EMA-qPCR & $9.03 \pm 0.29 \times 10^{2}$ & $7.01 \pm 0.56 \times 10^{2}$ & $6.22 \pm 0.44 \times 10^{2}$ & $6.08 \pm 0.26 \times 10^{2}$ & ND \\
\hline & EMA-qPCR $^{\mathrm{a}}$ & $4.45 \pm 0.33 \times 10^{3}$ & $7.20 \pm 0.43 \times 10^{2}$ & $2.89 \pm 0.39 \times 10^{3}$ & $5.67 \pm 0.26 \times 10^{3}$ & $6.33 \pm 0.23 \times 10^{2}$ \\
\hline & Plating & $4.62 \pm 0.58 \times 10^{3}$ & $4.49 \pm 0.42 \times 10^{1}$ & $2.93 \pm 0.87 \times 10^{3}$ & $5.79 \pm 0.26 \times 10^{3}$ & $6.42 \pm 1.21 \times 10^{2}$ \\
\hline & Plating $^{\mathrm{a}}$ & $4.69 \pm 0.66 \times 10^{3}$ & $4.52 \pm 0.69 \times 10^{1}$ & $2.95 \pm 0.92 \times 10^{3}$ & $5.81 \pm 0.26 \times 10^{3}$ & $6.49 \pm 0.79 \times 10^{2}$ \\
\hline \multirow[t]{5}{*}{ Total LAB } & QPCR & $3.10 \pm 0.57 \times 10^{6}$ & $8.34 \pm 0.56 \times 10^{4}$ & $5.17 \pm 0.57 \times 10^{4}$ & $1.23 \pm 0.54 \times 10^{4}$ & $9.78 \pm 0.56 \times 10^{4}$ \\
\hline & EMA-qPCR & $1.29 \pm 0.37 \times 10^{3}$ & $8.80 \pm 0.19 \times 10^{2}$ & $5.40 \pm 0.36 \times 10^{3}$ & $1.14 \pm 0.18 \times 10^{3}$ & $2.30 \pm 0.26 \times 10^{3}$ \\
\hline & EMA-qPCR $^{\mathrm{a}}$ & $2.78 \pm 0.41 \times 10^{4}$ & $8.89 \pm 0.26 \times 10^{3}$ & $9.98 \pm 0.44 \times 10^{3}$ & $8.32 \pm 0.51 \times 10^{3}$ & $5.42 \pm 0.26 \times 10^{4}$ \\
\hline & Plating & $2.88 \pm 0.78 \times 10^{4}$ & $1.87 \pm 0.59 \times 10^{2}$ & $1.19 \pm 0.48 \times 10^{4}$ & $8.44 \pm 0.72 \times 10^{3}$ & $5.55 \pm 1.02 \times 10^{4}$ \\
\hline & Plating $^{\mathrm{a}}$ & $2.92 \pm 0.90 \times 10^{4}$ & $1.84 \pm 0.70 \times 10^{2}$ & $1.17 \pm 0.81 \times 10^{4}$ & $8.49 \pm 0.88 \times 10^{3}$ & $5.65 \pm 0.88 \times 10^{4}$ \\
\hline \multirow[t]{5}{*}{ Non-O. oeni } & QPCR & $3.11 \pm 0.67 \times 10^{4}$ & $8.28 \pm 0.60 \times 10^{2}$ & $8.45 \pm 0.34 \times 10^{4}$ & $2.45 \pm 0.84 \times 10^{4}$ & $3.65 \pm 0.56 \times 10^{5}$ \\
\hline & EMA-qPCR & ND & ND & $6.79 \pm 0.41 \times 10^{3}$ & $8.02 \pm 0.42 \times 10^{2}$ & $9.18 \pm 0.34 \times 10^{2}$ \\
\hline & EMA-qPCR ${ }^{\mathrm{a}}$ & $7.02 \pm 0.29 \times 10^{2}$ & ND & $1.02 \pm 0.16 \times 10^{4}$ & $3.29 \pm 0.26 \times 10^{3}$ & $9.46 \pm 0.45 \times 10^{3}$ \\
\hline & Plating & $7.22 \pm 0.76 \times 10^{2}$ & ND & $1.09 \pm 0.68 \times 10^{4}$ & $3.41 \pm 0.59 \times 10^{3}$ & $9.61 \pm 0.77 \times 10^{3}$ \\
\hline & Plating $^{\mathrm{a}}$ & $7.29 \pm 0.59 \times 10^{2}$ & ND & $1.11 \pm 0.64 \times 10^{4}$ & $3.37 \pm 0.94 \times 10^{3}$ & $9.68 \pm 0.82 \times 10^{3}$ \\
\hline \multirow[t]{5}{*}{ Total AAB } & QPCR & $1.28 \pm 0.43 \times 10^{5}$ & $4.42 \pm 0.50 \times 10^{3}$ & $9.30 \pm 0.45 \times 10^{4}$ & $2.13 \pm 0.76 \times 10^{5}$ & $5.86 \pm 0.31 \times 10^{4}$ \\
\hline & EMA-qPCR & $8.05 \pm 0.27 \times 10^{2}$ & $8.28 \pm 0.27 \times 10^{2}$ & $2.05 \pm 0.37 \times 10^{3}$ & $9.21 \pm 0.51 \times 10^{2}$ & $8.11 \pm 0.29 \times 10^{2}$ \\
\hline & EMA-qPCR $^{\mathrm{a}}$ & $4.11 \pm 0.52 \times 10^{3}$ & $8.45 \pm 0.47 \times 10^{2}$ & $2.23 \pm 0.26 \times 10^{4}$ & $6.88 \pm 0.42 \times 10^{3}$ & $9.87 \pm 0.23 \times 10^{3}$ \\
\hline & Plating & $4.32 \pm 0.83 \times 10^{3}$ & $8.41 \pm 1.14 \times 10^{1}$ & $2.32 \pm 0.70 \times 10^{4}$ & $6.99 \pm 1.18 \times 10^{3}$ & $1.02 \pm 0.76 \times 10^{3}$ \\
\hline & Plating $^{\mathrm{a}}$ & $4.29 \pm 0.69 \times 10^{3}$ & $8.44 \pm 0.92 \times 10^{1}$ & $2.30 \pm 0.26 \times 10^{4}$ & $6.94 \pm 0.87 \times 10^{3}$ & $1.05 \pm 0.84 \times 10^{3}$ \\
\hline
\end{tabular}

${ }^{a}$ Cells were incubated in recovery medium for $40 \mathrm{~min}$ before enumeration. Standard deviations are from three independent replicates. 
a slight and reversible injury of cells including cell wall or membrane permeability and metabolic injury. However, cells can recover quickly and regain their normal physio-biochemical characteristics after incubation in a suitable medium at a suitable temperature. Traditionally, the growth/no growth response on selective media is the means of assessing sublethal injury (Brashears, Amezquita, \& Stratton, 2001). In our study, we describe a medium for the growth and recovery of the main microorganisms in wine, including yeasts, $\mathrm{LAB}$ and $\mathrm{AAB}$, and a EMA-qPCR method that can be used with or without a recovery medium incubation step to simultaneously quantify live and sublethally injured cells in wine. Compromised membranes caused by sublethal injury can be penetrated by EMA, but the membrane recovers after incubation in recovery medium, and EMA entry is blocked. All of the live cells can be enumerated by EMA-qPCR after incubation in recovery medium, and live cells, except for sublethally injured ones, can be enumerated by EMA-qPCR without incubation in recovery medium. Consequently, EMA can be successfully used as a potential probe to detect the sublethal injury of cells.

In the analysis of viable cells in contaminated wines, sublethally injured cells were detected by EMA-qPCR in almost all of the samples. Moreover, incubation in recovery medium for 40 min was used as an effective method to allow sublethally injured cells to recover without increasing cell number in wine. After incubation, the quantification results of five species by EMA-qPCR reached that of plate counts. In one wine sample, the result of EMA-qPCR was significantly higher than that of plate counts $(P<0.05)$, and this may due to the viable but not culturable state of cells in a stressed environment. In addition, qPCR without EMA results always gave larger population estimates than the plating and EMA-qPCR results due to qPCR amplification of DNA from both viable and non-viable cells.

In conclusion, our results describe a viable cell detection system for enumerating the main microorganisms in wine, including total yeasts, $S$. cerevisiae, total $\mathrm{LAB}$, non- $O$. oeni $\mathrm{LAB}$ and $\mathrm{AAB}$, based on EMA-qPCR method. Milling for $80 \mathrm{~s}$ by $\varnothing 500-\mu \mathrm{m}$ glass beads could be considered to be the optimized condition to extract sufficient DNA from these different microorganisms in wine. Moreover, EMA treatment $(10 \mu \mathrm{g} / \mathrm{mL}$ EMA concentration and $20 \mathrm{~min}$ photoactivation time) was determined for the EMA-qPCR method targeting wine microorganisms. In wine environment that can cause sublethal injury of cells, the enumeration result of EMA-qPCR was lower than the result of plate counting. Incubation in recovery medium for suitable time was used as an effective method to allow sublethally injured cells to recover without increasing cell number in wine. At last, EMA-qPCR method was successfully applied in various contaminated wines to enumerate different microorganisms.

\section{Acknowledgments}

This work was supported by the Ministry of Science and Technology of China (2011BAK10B02).

\section{References}

Abee, T., \& Wouters, J. A. (1999). Microbial stress response in minimal processing. International Journal of Food Microbiology, 50, 65-91.

Amerine, M. A., Berg, H. W., Kunkee, R. E., Ough, C. S., Singleton, V. L., \& Webb, A. D. (1980). Technology of wine making. Westport: CT Avi Publishing.

Amerine, M. A., \& Roessler, E. B. (1983). Wines-their sensory evaluation (2nd ed.). California: W. H. Freeman and Co.

Andorrà, I., Esteve-Zarzoso, B., Guillamón, J. M., \& Mas, A. (2010). Determination of viable wine yeast using DNA binding dyes and quantitative PCR. International Journal of Food Microbiology, 144, 257-262.
Brashears, M. M., Amezquita, A., \& Stratton, J. (2001). Validation of methods used to recover Escherichia coli 0157:H7 and Salmonella spp. subjected to stress conditions. Journal of Food Protection, 64, 1466-1471.

Dickson, J. S., \& Siragusa, G. R. (1994). Survival of Salmonella typhimurium, Escherichia coli 01 57:H7 and Listeria monocytogenes during storage on beef sanitized with organic acids. Journal of Food Safety, 14, 313-327.

Flekna, G., Polonca, S., Wagner, M., Smulders, F. J. M., Mozina, S. S., \& Hein, I. (2007) Insufficient differentiation of live and dead Campylobacter jejuni and Listeria monocytogenes cells by ethidium monoazide (EMA) compromises EMA/realtime PCR. Research in Microbiology, 158, 405-412.

González, A., Hierro, N., Poblet, M., Mas, A., \& Guillamón, J. M. (2006). Enumeration and detection of acetic acid bacteria by real-time PCR and nested PCR. FEMS Microbiology Letters, 254, 123-128.

Hierro, N., Esteve-Zarzoso, B., González, A., Mas, A., \& Guillamón, J. M. (2006). Realtime quantitative PCR (qPCR) and reverse transcription-qPCR for detection and enumeration of total yeasts in wine. Applied and Environmental Microbiology, 72, $7148-7155$.

Jara, C., Mateo, E., Guillamón, J. M., Torija, M. J., \& Mas, A. (2008). Analysis of several methods for the extraction of high quality DNA from acetic acid bacteria in wine and vinegar for characterization by PCR-based methods. International Journal of Food Microbiology, 128, 336-341.

López, R., López-Alfaro, I., Gutiérrez, A. R., Tenorio, C., Garijo, P., GonzálezArenzana, L., et al. (2011). Malolatic fermentation of Tempranillo wine: contribution of the lactic acid bacteria inoculation to sensory quality and chemical composition. International Journal of Food Science E Technology, 46, 2373-2381.

Lee, J. L., \& Levin, R. E. (2008). A comparative study of the ability of EMA and PMA to distinguish viable from heat killed mixed bacterial flora from fish fillets. Journal of Microbiological Methods, 76, 93-96.

Lemarchand, K., Berthiaume, F., Maynard, C., Harel, J., Payment, P., Bayardelle, P. et al. (2005). Optimization of microbial DNA extraction from raw wastewater samples for downstream pathogen detection by microarrays. Journal of Microbiological Methods, 63, 115-126.

Lopez, I., Ruiz-Larrea, F., Cocolin, L., Orr, E., Phister, T., Marshall, M., et al. (2003). Design and evaluation of PCR primers for analysis of bacterial populations in wine by denaturing gradient gel electrophoresis. Applied and Environmental Microbiology, 69, 6801-6807.

Martorell, P., Querol, A., \& Fernández-Espinar, M. T. (2005). Rapid identification and enumeration of Saccharomyces cerevisiae cells in wine by real-time PCR. Applied and Environmental Microbiology, 71, 6823-6830.

Neeley, E. T., Phister, T. G., \& Mills, D. A. (2005). Differential real-time PCR assay for enumeration of lactic acid bacteria in wine. Applied and Environmental Microbiology, 71, 8954-8957.

Nocker, A., Cheung, C. Y., \& Camper, A. K. (2006). Comparison of propidium monoazide with ethidium monoazide for differentiation of live vs. dead bacteria by selective removal of DNA from dead cells. Journal of Microbiological Methods, 67, 310-320.

Nogva, H. K., Drømtorp, S. M., Nissen, H., \& Rudi, K. (2003). Ethidium monoazide for DNA-based differentiation of viable and dead bacteria by $5^{\prime}$-nuclease PCR. BioTechniques, 34, 804-813.

Rawsthorne, H., \& Phister, T. G. (2009a). Detection of viable Zygosaccharomyces baili in fruit juices using ethidium monoazide bromide and real-time PCR. International Journal of Food Microbiology, 131, 246-250.

Rawsthorne, H., \& Phister, T. G. (2009b). The presence of Saccharomyces cerevisiae DNA in various media used to propagate yeasts and its removal by ethidium monoazide. Letters in Applied Microbiology, 49, 652-654.

Rea, M. C., Lennartsson, T., Dillon, P., Drinan, F. D., Reville, W. J., Heapes, M., et al. (1996). Irish kefir-like grains: their structure, microbial composition and fermentation kinetics. Journal of Applied Bacteriology, 81, 83-94.

Rudi, K., Moen, B., Drømtorp, S. M., \& Holck, A. L. (2005). Use of ethidium monoazide and PCR in combination for quantification of viable and dead cells in complex samples. Applied and Environmental Microbiology, 71, 1018-1024.

Ruiz, P., Izquierdo, P. M., Seseña, S., \& Palop, M. L. I. (2010). Analysis of lactic acid bacteria populations during spontaneous malolactic fermentation of Tempranillo wines at five wineries during two consecutive vintages. Food Control, 21, 70-75.

Saha, R. B., Sondag, R. J., \& Middlekauff, J. E. (1974). Proceedings of the American society of brewing chemists, 9th congress.

Shi, H., Xu, W., Luo, Y., Chen, L., Liang, Z., Zhou, X., et al. (2011). The effect of various environmental factors on the ethidium monazite and quantitative PCR method to detect viable bacteria. Journal of Applied Microbiology, 111, 1194-1204.

Tessonnière, H., Vidal, S., Barnavon, L., Alexandre, H., \& Remize, F. (2009). Design and performance testing of a real-time PCR assay for sensitive and reliable quantification of Brettanomyces in wine. International Journal of Food Microbiology, 129, 237-243.

Versari, A., Parpinello, G. P. \& Cattaneo, M. (1999). Leuconostoc oenos and malolactic fermentation in wine: a review. Journal of Industrial Microbiology and Biotechnology, 23, 447-455.

Williamson, K. E., Kan, J., Polson, S. W., \& Williamson, S. J. (2011). Optimizing the indirect extraction of prokaryotic DNA from soils. Soil Biology E Biochemistry, 43, 736-748.

Witthuhn, R. C., Schoeman, T., \& Britz, T. J. (2004). Isolation and characterization of the microbial population of different South African kefir grains. International Journal of Dairy Technology, 57, 33-37. 